\title{
Photochemical and Dynamical Contributions to the Seasonal Variation of Total Ozone Amount over Japan
}

\author{
By Toshiki Iwasaki* and Susumu Kaneto \\ Sapporo District Meteorological Observatory, Sapporo 060, Japan \\ (Manuscript received 23 February 1983, in revised form 22 February 1984)
}

\begin{abstract}
The latitudinal and seasonal variations of ozone photochemical process are analyzed using the monthly means of ozone density observed by ozonesondes at Sapporo, Tateno and Kagoshima. The estimated photochemical change rate (creation minus destruction) and observed ozone density variation are used to evaluate the divergence of ozone.

The seasonal variation of total ozone amount at Kagoshima is mainly due to the density variation in the quasi steady region, where the photochemical change rate of ozone density is effectively balanced with its divergence. On the other hand, the variation at Sapporo is dominated by the dynamical process in the non-steady region. In this case, the primary effect in the dynamical process is the seasonal variation of tropopause height and the secondary one is the accumulation in the lower stratosphere due to the meridional circulation in winter. The former tends to set the time of maximum of total ozone amount in mid-winter and the latter shifts it to early spring. Especially, the continuous increase in the total ozone amount during winter is an evidence that the distribution of ozone remains at a transient state for the winter circulation. Such a remarkable difference between the mechanisms of the seasonal variation of total ozone amount in the two stations is originated from the variation of tropopause structure. The major tropopause that effectively separates the stratospheric air mass from the tropospheric one is the tropical tropopause through all seasons over Kagoshima, but it is the tropical one in summer and the polar one in winter over Sapporo.

Finally, from the view point of the longitudinal dependence, the ozone distribution over Japan is discussed.
\end{abstract}

\section{Introduction}

It is well-known that the total ozone amount shows a large seasonal variation with summer maximum in low latitudes and spring maximum in high latitudes (Dütsch, 1971). Both photochemical and dynamical processes contribute to this variation. But the latitudinal dependence of this variation has not been quantitatively explained enough.

The mechanism that causes the poleward transport of ozone is one of the most important problems on the dynamical process that

* Present address : Electronic Computation Center, Japan Meteorological Agency, Tokyo 100, Japan. maintains the observed ozone distribution. The observed fact that the total ozone amount in high latitudes is larger than in low latitudes cannot be explained by Eulerian mean meridional circulations, which show two cells structure in the stratosphere over a hemisphere (e.g., Newell et al., 1972). Reed and German (1965) showed that the diffusive tensor based on the mixing length hypothesis is able to account for the poleward ozone transport. Using a global numerical model, Schlesinger and Mintz (1979) showed that in mid-latitudes the eddy transport of ozone toward the pole is larger than the zonal mean one toward the equator and the net transport becomes poleward. Their discussions on the ozone trans- 
port were performed in the Eulerian framework. Matsuno (1980) showed that the transport of conservative tracers should be understood in the Lagrangian framework to get more clear-cut physical picture. The numerical experiments by Kida $(1977,1983)$ showed that the meridional circulation in the Lagrangian framework has a single cell structure as the circulation proposed by Brewer (1949) and Dobson (1956). Especially, the downward motion in high latitudes explains the vertical transport well. For the horizontal transport, the diffusion is also important even in the Lagrangian framework, as shown by Pyle and Rogers (1980) and Kida (1983). Thus, the dynamical process of the meridional transport of ozone has been at least qualitatively established.

The meridional circulation of air mass may have a large seasonal variation, which will induce the variation of ozone density. In fact, the air mass transport numerically simulated in the Lagrangian framework by Holton and Wehrbein (1980) seems to be consistent with the variation of meridional flux of ozone reported by Harwood and Pyle (1977). Cunnold et al. (1975) reproduced the seasonal variation of ozone distribution using a global model except for unrealistic total ozone amount in the high latitudes; in their model the time of maximum of total ozone amount is earlier and its amplitude is smaller than the observation. While, the total air mass of hemispheric stratosphere in summer is $30 \%$ smaller than in winter (Robinson, 1980). The ozone mixing ratio in the stratosphere is far larger than that in the troposphere. Therefore, when we analyze the seasonal variation of ozone density, we should consider the variation of stratospheric air mass amount as well as that of the meridional circulation.

The aim of this work is to analyze the seasonal variation of observed ozone density over Japan taking account of both view points of the photochemical and dynamical processes. Fig. 1 shows the seasonal variation of total ozone amount observed at Japanese stations (Sakai et al., 1980). Sekiguchi and Kida (1971) tried to decompose this variation into photochemical and dynamical contributions, although

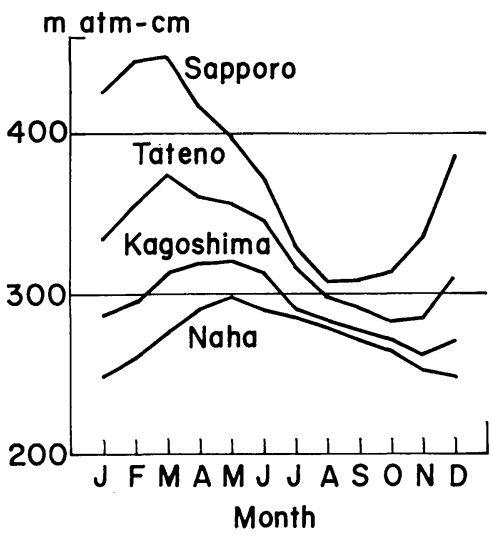

Fig. 1 Seasonal variations of total ozone amount at Sapporo, Tateno, Kagoshima and Naha, based on monthly means (Sakai et al., 1980).

they did not evaluate the photochemical term explicitly. There are large vertical, latitudinal and seasonal variations in the photochemical creation and destruction rates of ozone. According to the knowledge on the minor constituents and photochemical reactions in the stratosphere (e.g., Shimazaki and Ogawa, 1974), the ozone photochemistry below the lower stratosphere is almost described by the pure oxygen cycle, and catalytic cycles of $\mathrm{NO}_{x}$, $\mathrm{HO}_{x}$ and $\mathrm{ClO}_{x}$. In the present work, therefore, the monthly change rate (creation minus destruction) of ozone due to the photochemistry is estimated using a realistic photochemical model. The transport of ozone will be treated as a difference between the photochemical change and observed density variation.

\section{Observed Data}

In this study, the observed data used are monthly means of temperature and the densities of water vapor and ezone. The observation of ozone density by ozonesondes is routinely conducted at three stations (JMA's Aerological Data); Sapporo $\left(43.1^{\circ} \mathrm{N}, 141.3^{\circ} \mathrm{E}\right)$, Tateno $\left(36.1^{\circ} \mathrm{N}, 140.1^{\circ} \mathrm{E}\right)$ and Kagoshima $\left(31.6^{\circ} \mathrm{N}, 130.6^{\circ} \mathrm{E}\right)$. The numbers of soundings for a given month are shown in Table 1 . These are large enough to determine the monthly means except for July and August at Tateno. Fig. 2 shows the seasonal variations of ozone density. The ozone amount vertically integrated from $1000 \mathrm{mb}$ to $10 \mathrm{mb}$ 
Table 1 Number of ozonesondes for each month at Sapporo, Tateno and Kagoshima (1968-1979).

\begin{tabular}{lcccccccccccc} 
Stations & 1 & 2 & 3 & 4 & 5 & 6 & 7 & 8 & 9 & 10 & 11 & 12 \\
\hline Sapporo & 18 & 21 & 21 & 21 & 17 & 16 & 20 & 17 & 16 & 22 & 24 & 23 \\
\hline Tateno & 21 & 22 & 32 & 26 & 20 & 14 & 4 & 3 & 18 & 25 & 25 & 23 \\
\hline Kagoshima & 24 & 14 & 18 & 19 & 19 & 14 & 16 & 14 & 17 & 19 & 17 & 17 \\
\hline
\end{tabular}

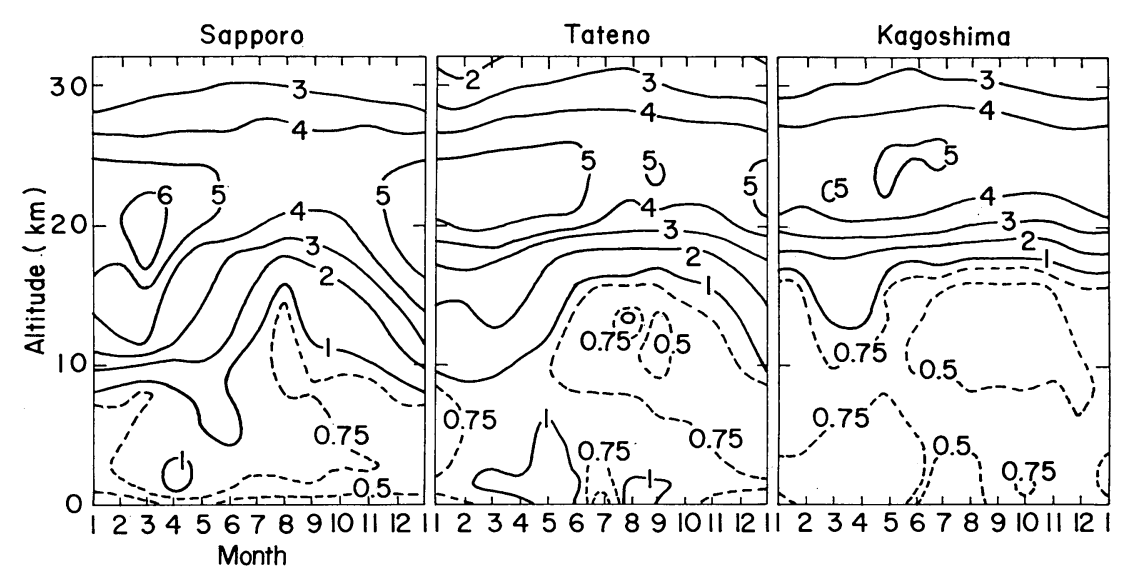

Fig. 2 Seasonal variations of the vertical distribution of ozone at Sapporo, Tateno and Kagoshima, based on the monthly mean data of ozonesonde observations. (unit : $10^{12} \mathrm{~cm}^{-3}$ )

levels contains $80 \sim 90 \%$ of total ozone amount and is the main cause of the seasonal variation of total ozone amount.

Water vapor observations by radiosondes in the lower troposphere and by dew (frost)-point radiosondes in the higher troposphere and stratosphere are used. The data of dew (frost)point radiosondes are calibrated using the method reported by Toyama (1979). The initial data of water vapor above the altitude of about $20 \mathrm{~km}$ are carefully smoothed, because the numbers of dew (frost)-point radiosondes which reached so high altitudes are small. The vertical distribution of water vapor shows a minimum mixing ratio near the tropopause, as also observed by the ultraviolet fluorescence method (Kley et al., 1979). This phenomenon is usually explained by the existence of water vapor source, for example, the oxidation of $\mathrm{CH}_{4}$ in the stratosphere (Crutzen, 1973). Muramatsu (1981), however, suggested that the water vapor density at high altitude observed by dew (frost)-point radiosondes was too large to be explained by the oxidations and might be over-estimated because of the observational inaccuracy followed with the contamination from the instrument. Even if such the uncertainty remains in the density of water vapor, it is not probably sensitive to our problem, because the ozone destruction in the upper stratosphere is dominated by the $\mathrm{NO}_{x}$ catalytic cycle (e.g., Crutzen, 1971).

\section{Photochemical Model}

The continuity equation for the constituent with the photochemical creation and destruction is given by

$$
\frac{\partial}{\partial t} \rho+\nabla \cdot \phi=Q
$$

where $\rho, \phi$ and $Q$ are the constituent density, flux and photochemical change rate (creation minus destruction), respectively. Each term is evaluated by the monthly mean value, 
because our main attention is paid for the seasonal variation. The change rate $Q$ of ozone over Japan is estimated by the photochemical model based on the observed data. The creation and destruction rates of ozone show large diurnal variations induced by the variations of solar zenith angle and other constituent densities, so that the photochemical model needs to contain the diurnal variation explicitly. In our model, the time step is 12 minutes. The vertical levels are same as the standard pressure levels of 30 layers for ozonesondes. The photochemical reactions associated with atmospheric ozone are very complicated (e.g., Shimazaki and Ogawa, 1974). In order to exclude the ambiguity of arbitrary parameters, our photochemical scheme below the altitude of $30 \mathrm{~km}$ is restricted to the dominant reactions of pure oxygen cycle and catalytic cycles of $\mathrm{HO}_{x}$ and $\mathrm{NO}_{x}$ according to an order estimation (Fig. 3). The catalytic cycle of $\mathrm{ClO}_{x}$ is not effective for the ozone destruction below the altitude of $30 \mathrm{~km}$. The detailed surface process will not be taken into account in our model, because the existence of localized

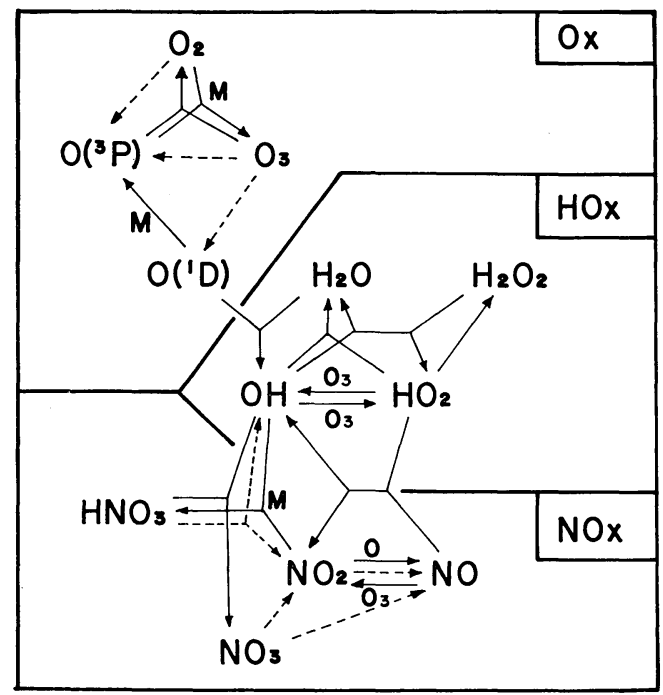

Fig. 3 Photochemical process considered in our scheme. This is restricted to the significant reactions below the altitude of $30 \mathrm{~km}$. The solid lines indicate the chemical reactions (collisions) and the broken lines indicate the photochemical reactions (photodissociations). The $\mathrm{O}_{x}, \mathrm{HO}_{x}$ and $\mathrm{NO}_{x}$ denote the pure oxygen cycle and catalytic cycles of $\mathrm{HO}_{x}$ and $\mathrm{NO}_{x}$, respectively. characters as sea-land distribution, plants and man-made products complicates the actual reactions near the surface (e.g., Galbally and Roy, 1980).

As mentioned above, the distribution of $\mathrm{NO}_{x}$ is necessary for our model. The source and sink of $\mathrm{NO}_{x}$ are the oxidation of $\mathrm{N}_{2} \mathrm{O}$ and the rain-out effect of water-soluble components, respectively, but its chemical relaxation time is too long to be explicitly treated in our model. The best way for our model is to use the observed values of $\mathrm{NO}_{x}$ as initial data. However, there are large differences among the observations of $\mathrm{NO}_{x}$ (Ogawa et al., 1981). Therefore, the distribution of $\mathrm{NO}_{x}$ theoretically obtained by Hidalgo and Crutzen (1977), whose vertical profile is like to the averaged profile of observations, is used in our model, but its seasonal and latitudinal variations are neglected. In the troposphere, the distribution of $\mathrm{NO}_{x}$ may have a large seasonal variation affected by rain-out process. It, however, does not give any large contribution to the destruction rate of ozone except for near the surface in comparison with the $\mathrm{HO}_{x}$ catalytic cycle.

The reaction chains with the shorter relaxation time than 12 minutes, for example, pure oxygen cycle and the ratios of $\mathrm{OH}$ to $\mathrm{HO}_{2}$ and $\mathrm{NO}$ to $\mathrm{NO}_{2}$, are assumed to be in photochemical equilibriums. The constituents, whose relaxation times are longer than one day and far shorter than one year, are obtained from balancing the daily total creation with destruction. The densities of constituents with mid-range relaxation times longer than 12 minutes and shorter than one day are predicted from the time integration of rate equations based on the relaxation method.

\section{Results and Discussions}

\subsection{Photochemical Creation and Destruction Rates of Ozone}

As mentioned above, we consistently decide all the densities of 12 kinds of minor constituents from the densities of ozone, water vapor and $\mathrm{NO}_{x}$. Their vertical profiles and diurnal variations almost agree with the previous results (e.g., Shimazaki and Ogawa, 1974), so that the obtained photochemical creation and destruction rates of ozone may be available 
for the analysis on the seasonal variation of ozone density. Fig. 4 shows the seasonal variation of the life time of ozone over Sapporo. In the troposhere, it has a extremely large variation. The life time of tropospheric ozone is dominated by the destruction due to the $\mathrm{HO}_{x}$ catalytic cycle. The density of $\mathrm{HO}_{x}$ is proportional to the densities of $\mathrm{O}\left({ }^{1} \mathrm{D}\right)$ and water vapor. The $\mathrm{O}\left({ }^{1} \mathrm{D}\right)$ is mainly produced by the photodissociation of ozone in Hartley

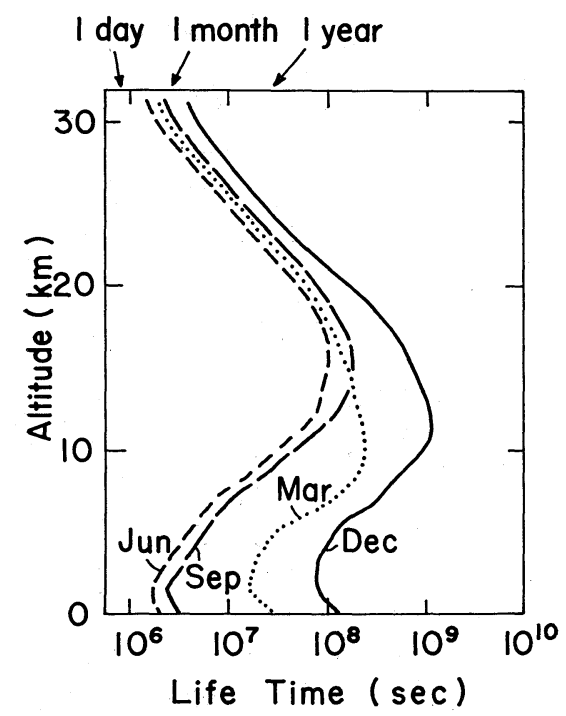

Fig. 4 Ozone life times in March, June, September and December over Sapporo.

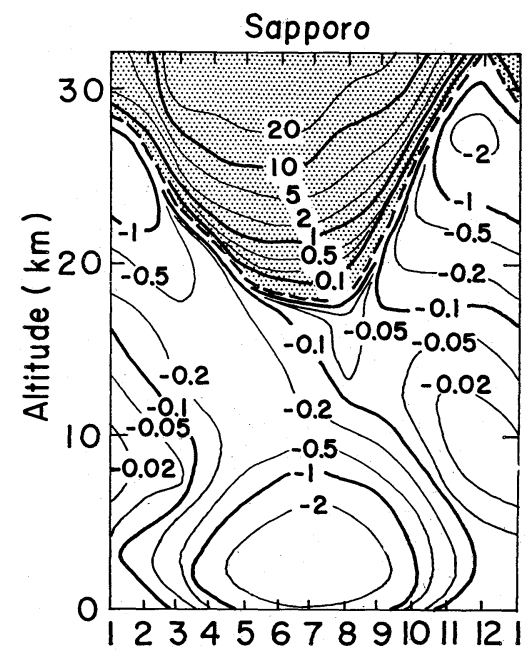

continuum, which is rapidly damped by the absorption of ozone, depends strongly on the solar zenith angle. Therefore, the seasonal variation of solar radiative conditions gives the variation to the $\mathrm{O}\left({ }^{1} \mathrm{D}\right)$ density. The density of water vapor is strongly affected by the temperature. For example, in the troposphere over Sapporo, the water vapor density in winter is an order of magnitude smaller than in summer. Hence, both densities of $\mathrm{O}\left({ }^{1} \mathrm{D}\right)$ and water vapor cause a large seasonal variation of life time there. The life time in September is far shorter than in March. This is mainly induced by the difference in the water vapor density, because the solar radiative condition is nearly equal to each other.

In the stratosphere, the life time in summer is several times shorter than in winter and this seasonal variation is mainly induced by the radiative conditions of solar zenith angle and the day time length. The life time in March is a little shorter than in September. This is induced by the difference in the ozone density itself due to the existence of nonlinear effects in the ozone photochemistry, because the $\mathrm{HO}_{x}$ density and the ratio of NO to $\mathrm{NO}_{2}$, to which the destruction rate of ozone is sensitive, depend on the ozone density.

Fig. 5 shows the photochemical change rate $Q$ of ozone over Sapporo and Kagoshima.

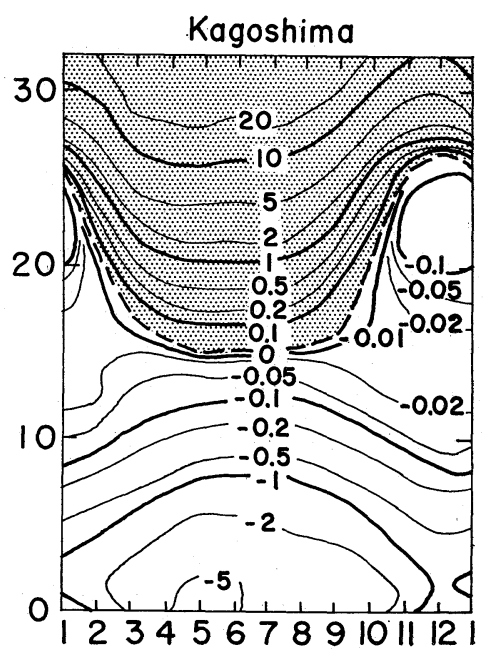

Fig. 5 Seasonal variations of photochemical change rate $Q$ of ozone (creation minus destruction) at Sapporo and Kagoshima. Net creative regions are shadowed. (unit: 10 $0^{10}$ $\mathrm{cm}^{-3}$ day $\left.^{-1}\right)$. 

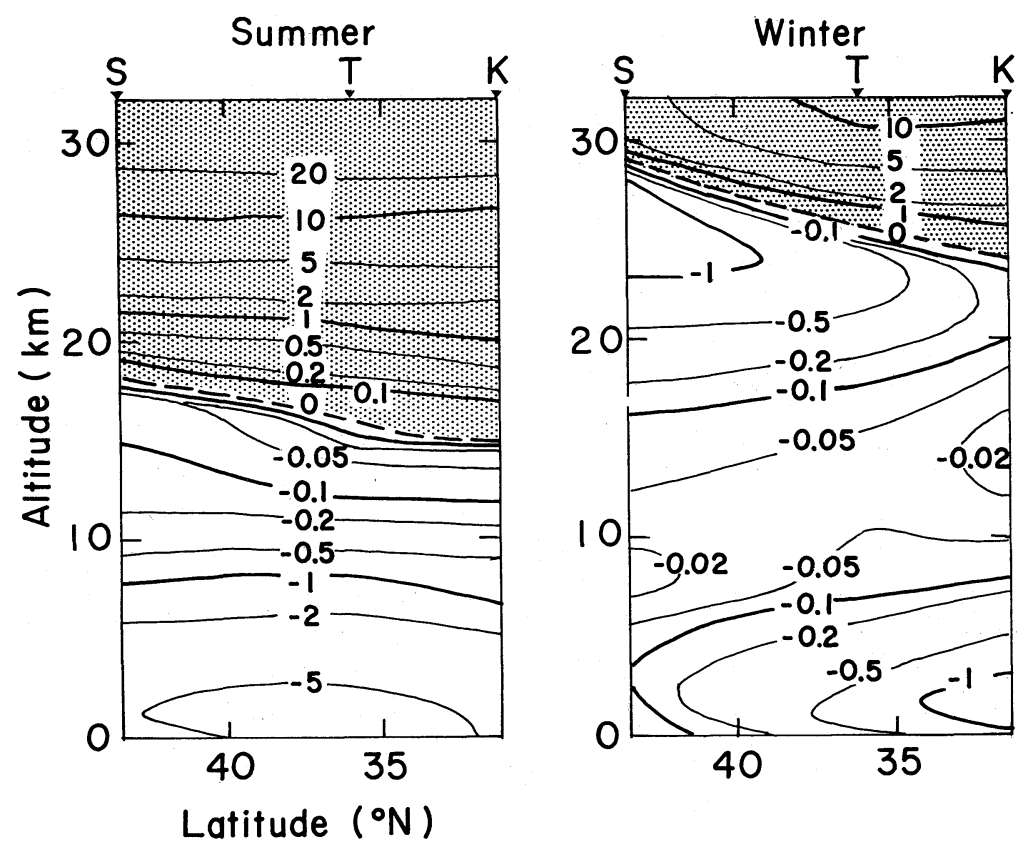

Fig. 6 Latitudinal variations of photochemical change rate $Q$ of ozone in summer and winter, drawn by the calculated results for three stations. Net creative regions are shadowed. (unit: $10^{10} \mathrm{~cm}^{-3} \mathrm{day}^{-1}$ ).

S: Sapporo T: Tateno K: Kagoshima

The rate determinant reaction for ozone creation is the photodissociation of $\mathrm{O}_{2}$ in Herzberg continuum. Since the optical thickness of the atmosphere for this band is very large, the ozone creation rate at any level depends strongly on the solar zenith angle and is large in summer and small in winter as the destruction rate. In the stratosphere, the seasonal variation of creation rate is larger than the destruction. Therefore, the change rate $Q$ becomes a maximum in summer. In the troposphere, the creation rate is so small that the change rate $Q$ is nearly equal to the destruction rate. Fig. 6 shows the meridional cross section of the change rate $Q$. Both in the stratosphere and troposphere, the change rate $Q$ depends strongly on the latitude in winter than in summer. In the stratosphere, the main cause of this latitudinal dependence is the radiative condition. Especially, in winter, the creation rate is nearly equal to the destruction one in the altitude near $25 \mathrm{~km}$ over Kagoshima, but a maximum of net destruction is formed in this altitude over Sapporo. Prob- ably, the maximum of the net destruction of stratospheric ozone in meridional plane exists in just northern side of Sapporo in winter, because the weak solar irradiance near the pole makes the destruction rate extremely small as well as the creation rate. On the other hand, the change rate in the troposphere is mainly induced by the distribution of water vapor density, which is very sensitive to temperature. The larger latitudinal gradient of temperature results in a larger gradient of the change rate $Q$ in winter than in summer.

\subsection{Steady and Non-steady States in the Seasonal Variation of Ozone Transport}

The continuity equation for the constituent with the chemical creation and destruction is given by equation (1). According to the properties of photochemical and dynamical contributions to the seasonal variation of ozone density, we can classify the ozone budgets as follows,

i) photochemical equilibrium state (PE), where 
$\left|\frac{\partial \rho}{\partial t}\right| \ll$ creation, $|\nabla \cdot \phi| \ll$ creation

and creation $\doteqdot$ destruction

ii) quasi photochemical-dynamical equilibrium state (PDE), where

creation $\neq$ destruction,

$$
\left|\frac{\partial \rho}{\partial t}\right| \ll|Q| \text { and } \nabla \cdot \phi \doteqdot Q
$$

iii) dynamical non-steady state (DNS), where

$$
|Q| \ll\left|\frac{\partial \rho}{\partial t}\right| \text { and } \frac{\partial \rho}{\partial t} \doteqdot-\nabla \cdot \boldsymbol{\phi} .
$$

In an equilibrium state (i), the ozone density is theoretically determined from balancing daily total creation with destruction. In another quasi equilibrium state (ii), the photochemical change rate $Q$ is effectively compensated with the transport process, so that both photochemical and dynamical processes are important for the seasonal variation of ozone density. In the non-steady state (iii), the seasonal variation of ozone density is hardly influenced by the photochemical process but is dominated by dynamical process.

In the case of ozone, the photochemical equilibrium is not realized below the altitude of $30 \mathrm{~km}$. In order to distinguish the PDE and DNS states, a parameter $\gamma$ defined by

$$
\gamma=\frac{|Q|}{\left|\frac{\partial \rho}{\partial t}\right|+|Q|}
$$

is used. The $\gamma$ is unity at the PDE state and zero at the DNS state. Fig. 7 shows the time cross section of $\gamma$ at Sapporo and Kagoshima. As mentioned in the previous section, above the altitude of $20 \mathrm{~km}$ both creative and destructive reactions of ozone are active and in the lower troposphere the destructive reaction is active. Hence, in these regions the $\gamma$ approaches to unity. On the contrary, reflecting the inactivity of the ozone photochemistry, the $\gamma$ is close to zero near the altitudinal region of $15 \mathrm{~km}$.

As shown previously in Fig. 2, the seasonal variation of total ozone amount at Sapporo is mainly caused by the density variation in the DNS region in the altitude of $10 \sim 20 \mathrm{~km}$. Therefore, the dynamical process plays a major role in the seasonal variation of total ozone amount. On the other hand, the DNS region over Kagoshima is narrower and the variation of ozone density in this region is far smaller than Sapporo. The density variation in the stratospheric $\mathrm{PDE}$ region above the altitude of $20 \mathrm{~km}$ is the main cause of the
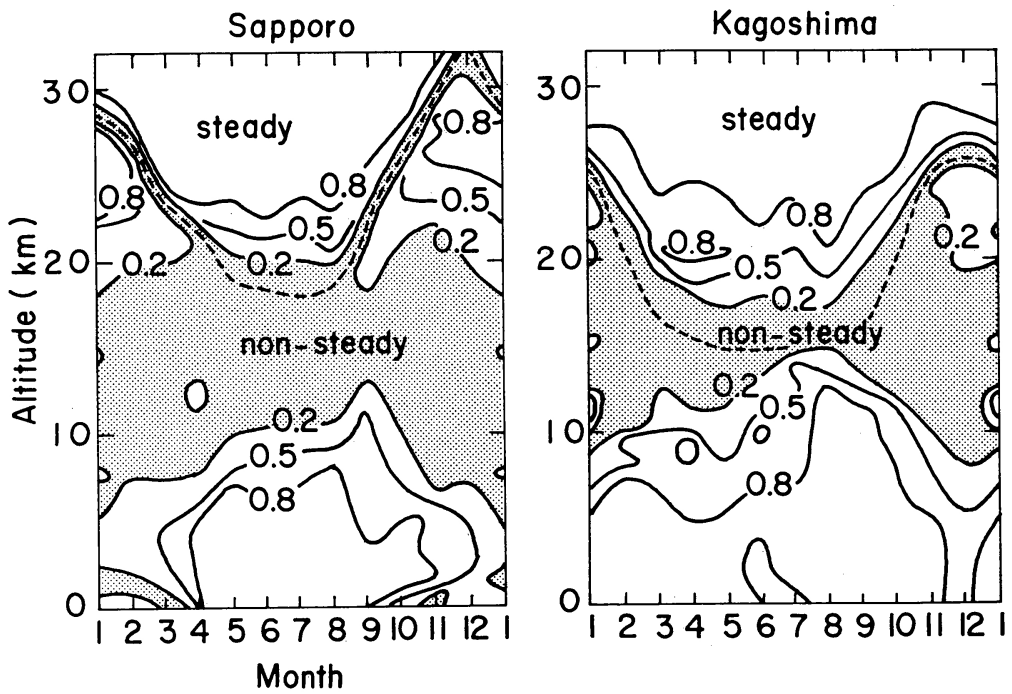

Fig. 7 Seasonal variations of $\gamma$ at Sapporo and Kagoshima, where the $\gamma$ is defined by the equation (5). Non-steady states (DNS: $\gamma<0.2$ ) are shadowed. The broken lines $(\gamma=0)$ indicate levels at which the ozone destruction rates are equal to the creation rates. 
variation of total ozone amount. Hence, the variation of photochemical change rate with a summer maximum may play an important role. The actual maximum of total ozone amount occurs in late spring and precedes the maximum of the photochemical change rate at Kagoshima. This time shift is caused by the dynamical effect.

Thus, the mechanism of seasonal variation of total ozone amount at Sapporo is very different from that at Kagoshima. This difference is principally related with the atmospheric structure neare the tropopause. Fig. 8 shows the tropopause structure near Japan, illustrated by use of histograms of daily tropopause heights at the stations in Japan and USSR. In the histograms, the intermediate and polar tropopauses are inseparable, but the tropical tropopause apparently separates from the polar one. Especially, at the station located near the latitudinal region of the jet stream, both tropopauses are often observed at a time and two peaks appear in the histogram. The polar tropopause switches to the tropical one at about $35^{\circ} \mathrm{N}$ in winter and $45^{\circ} \mathrm{N}$ in summer. Generally, this annual oscillation corresponds to that of the latitudinal position of the jet stream, because the switching of tropopauses occurs near the jet stream.
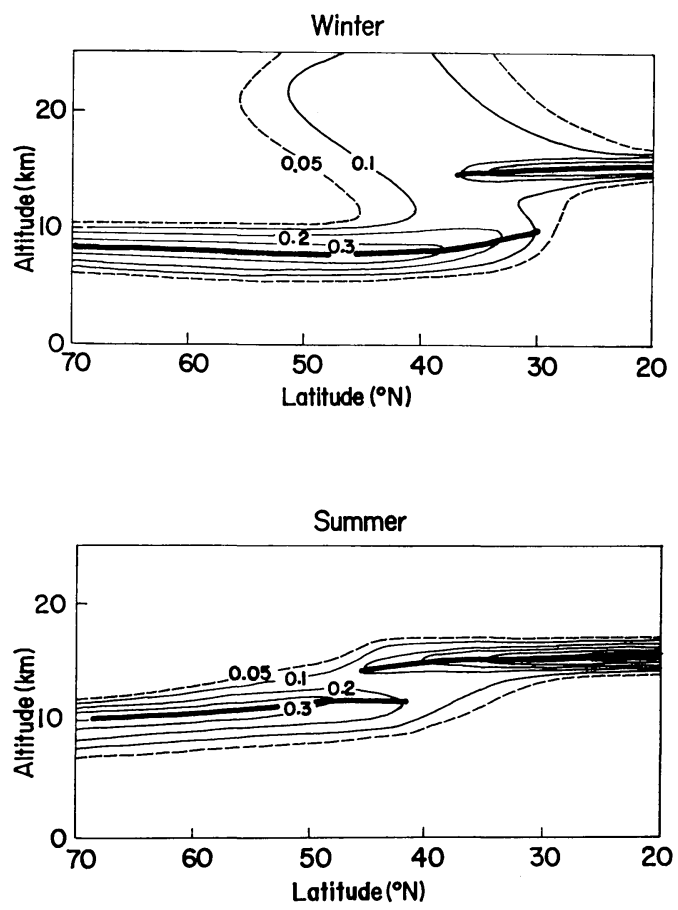

Fig. 8 Meridional cross sections of seasonal mean tropopause structure (heavy lines) in summer and winter near the far east region, illustrated by use of the histograms of tropopause heights at the stations in Japan and USSR, where the light lines indicate the frequency observing tropopause per $1 \mathrm{~km}$ height.
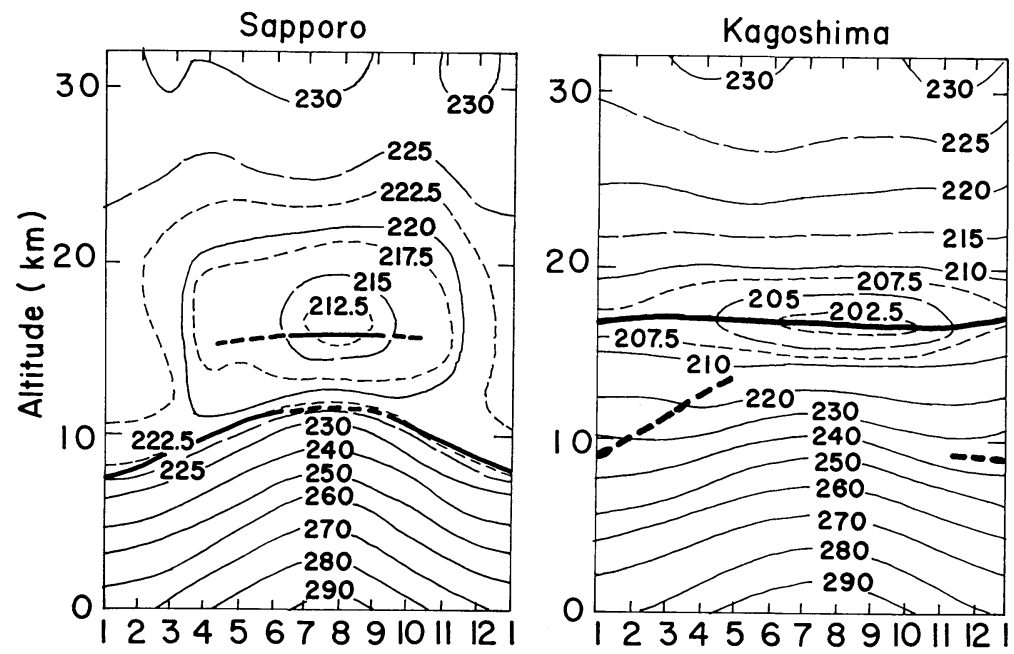

Fig. 9 Seasonal variations of tropopause height at Sapporo and Kagoshima. Heavy solid and broken lines indicate the peak positions in the histograms of tropopause heights and are regarded as the major and minor tropopauses, respectively, by considering the monthly mean temperature profiles (light lines, unit: K). 
As another seasonal variation of tropopause structure, one can point out that the height of the polar tropopause in winter is $2 \sim 4 \mathrm{~km}$ lower than in summer. These two effects lead a large change in the tropopause height in mid- and high latitudes. Fig. 9 shows the seasonal variation of the observed tropopause height at Sapporo and Kagoshima, based on the histograms for any month. In the case that there are two or more peaks in the histogram for a month, the major tropopause is selected by considering monthly mean temperature. The total ozone amount strongly connects with the tropopause height, because the ozone density abruptly increases just above the tropopause. At Kagoshima, the polar tropopause often appears under the tropical one, but the ozone-rich stable layer above the polar tropopause is very thin. Therefore, the major tropopause is the tropical one through all seasons and the seasonal variation of total ozone amount is mainly caused by the density variation above the tropical tropopause (Fig. 2). On the other hand, at Sapporo, the major tropopause is the polar one with the altitude of about $8 \mathrm{~km}$ in winter and the tropical one with that of $15 \mathrm{~km}$ in summer and its seasonal variation is the main cause of variation of the total ozone amount. If only the seasonal variation of tropopause height contributes to the variation of total ozone amount, its maximum will take place in mid-winter. The actual maximum, however, occurs in early spring. This time lag may be partially explained by the variation of photochemical change rate, but is mostly caused by the dynamical effect in the DNS region. This dynamical effect is discussed in detail in the next section.

\subsection{Dynamical Effect on the Seasonal Variation of Total Ozone Amount}

The transport of conservative tracers had better be treated in the Lagrangian framework, because the meridional circulation in the Eulerian framework contains an ambiguity with the tracer transport in the existence of well-developed planetary waves as suggested by Mastuno (1980). Holton (1980) showed that the vertical and horizontal transports of ozone in the stratosphere in the Lagrangian frame- work can be well represented by the mean motion and by the diagonal element of diffusive tensor, respectively. Also, the numerical experiment by Pyle and Rogers (1980) showed that the horizontal diffusion plays an important role in the ozone transport. In fact, the slow horizontal velocity of Lagrangian mean seems to be inconsistent with the small latitudinal gradient of ozone mixing ratio above the altitude of $25 \mathrm{~km}$ in winter (Fig. 6). Because the photochemical change rate in winter depends strongly on the latitude and its relaxation time is shorter than $10^{7} \mathrm{~s}$ in this region. On the other hand, the vertical transport of ozone in the stratosphere is mainly performed by the mean motion in comparison with the vertical diffusion owing to the high stability of vertical profile of temperature. As shown by Kida (1977, 1983), the hemispheric meridional circulation in the Lagrangian framework has a single-cell structure which consists of downward motion in the polar side of the jet stream and upward motion in the equatorial side. Then, the adiabatic heating due to the vertical motions maintains the meridional patterns of the tropopause structure. Therefore, the fall extension of the stratosphere means the strengthening of downward motion. Of course, such the vertical motion directly influences the ozone transport as well as the heat transport.

Fig. 10 shows the convergence of ozone which is determined from the continuity equation (1) by calculating $\partial \rho / \partial t-Q$, where $Q$ and $\partial \rho / \partial t$ have been given from the photochemical model and observation, respectively. Generally, the tropopause structures in fall and in spring resemble each other. Nevertheless, the DNS region in the altitude of $10 \sim 20 \mathrm{~km}$ becomes a convergence area of ozone in fall but does a divergence one in spring. This clear difference means that the seasonal variation of stratospheric air mass plays an important role in the density variation of ozone in the DNS region. Of cource, at Sapporo, this variation is the main cause of the seasonal variation of total ozone amount. In fall, the increase in the stratospheric air mass is at least partially supplied by the downward transport of upper stratospheric mass with 

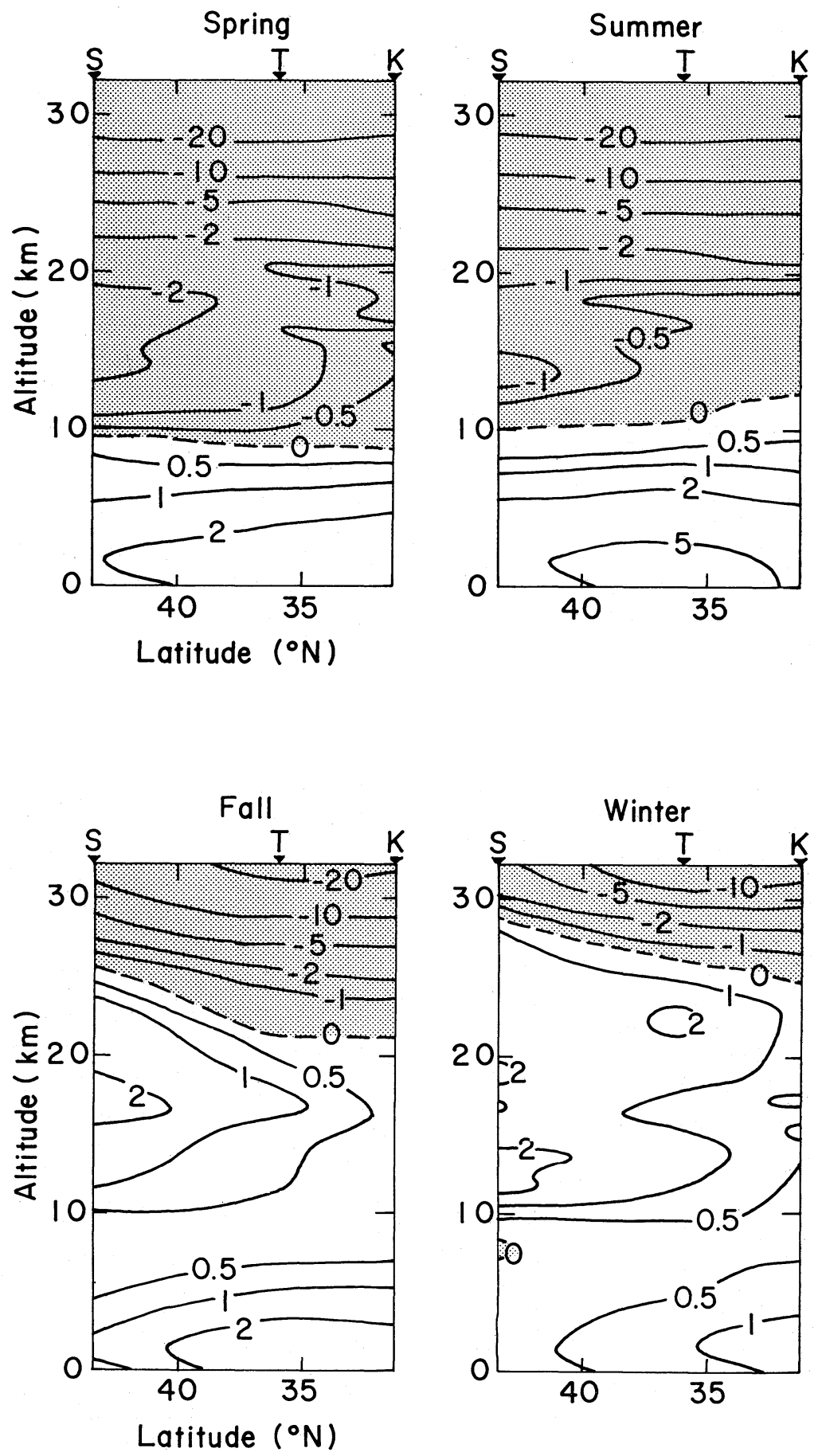

Fig. 10 Latitudinal variations of ozone convergence (divergence) in spring, summer, fall and winter. The divergence regions are shadowed. (unit: $10^{10} \mathrm{~cm}^{-3} \mathrm{day}^{-1}$ ). 
the high mixing ratio of ozone, so that the ozone density in the DNS region increases. On the other hand, in spring the decrease in the stratospheric air mass accelerates the ozone transfer from the stratosphere to the troposphere. It is consistent with the fact that the tropospheric ozone density has a maximum in spring. Muramatsu (1980) showed in his case study over Japan that the insertion of ozone-rich stable layer into the troposphere often occurs in spring. However, the ozone density in the troposphere is still much lower than in the stratosphere, because the ozone released to the troposphere is rapidly diffused and destroyed near the surface. Therefore, a divergence area is formed in the DNS region in spring.

The ozone continues to converge in the lower stratosphere even during winter when the extension of stratosphere ends. It means that the ozone distribution still remains at a transient state for the winter circulation. If all of the fall increase in the stratospheric mass is supplied only by the downward mass transport from the upper stratosphere, the meridional circulation can not increase the ozone density any more in the lower stratosphere in winter owing to the saturation of ozone mixing ratio. Therefore, it is sure that the fall increase in the stratospheric air mass is partially supplied by the direct capture of tropospheric mass near the tropopause. For example, over Sapporo, though the stratospheric mass in winter is three times larger than in summer, the amplitude of total ozone amount is not so large. This is originated from the fact that the mixing ratio in the lower stratosphere is far smaller than in the upper stratosphere. Main rarefaction of ozone mixing ratio in the lower strotosphere is due to the mixing with the ozone-poor tropospheric mass, because the photochemical destruction rate is negligibly small compared to the period of mass transport from the tropical tropopause level to the polar one. Even in mid-winter, the difference between the mixing ratios in the upper and lower stratospheres still remains large enough for the meridional circulation to continuously increase the mixing ratio in the lower stratosphere. The existence of this accumulation effect of ozone results in the spring maximum of total ozone amount in mid- and high latitudes.

\subsection{Longitudinal Dependence of Total Ozone Amount}

In the view point of the longitudinal dependence of total ozone amount, one should pay his attention for the fact that its distribution reflects the pattern of ultra-long waves in mid- and high latitudes (e.g., Schlesinger and Mintz, 1979).

In the upper PDE region (above the altitude of $20 \mathrm{~km}$ ), the radiative condition depends less on the longitude. The circulation around the pole is very active in comparison with the vertical motion and the horizontal redistribution of ozone is diffusive. Considering these facts, the ozone distribution in this region is expected to have an axial symmetry well. In the troposphere, the photochemical change rate $Q$, which depends on the water vapor density and temperature, may have a large longitudinal dependence. But both horizontal and vertical diffusions rapidly transport the ozone to the active destructive region, so that the mixing ratio of ozone is depressed at a quite low level in the whole troposphere. At last, the longitudinal dependence of total ozone amount is mainly due to the ozone density in the DNS region.

Reiter and Gao (1982) showed in their analysis on the satellite data by the total ozone mapping spectrometer, the daily patterns of total ozone amount vary with the transformation of planetary wave, where the large horizontal gradients of total ozone amount correspond to the positions of jet stream. Their results suggested that the short-period variation of total ozone amount as several days is directly related with the variation of tropopause height, because the switching of the tropopause occurs near the jet stream. Fig. 11 shows monthly means of northern hemispheric distributions of trapopause pressure level and total ozone amount. Also in the monthly means, it is evident that the distribution of total ozone amount is related with the stationary ultra-long wave through the tropopause height. 


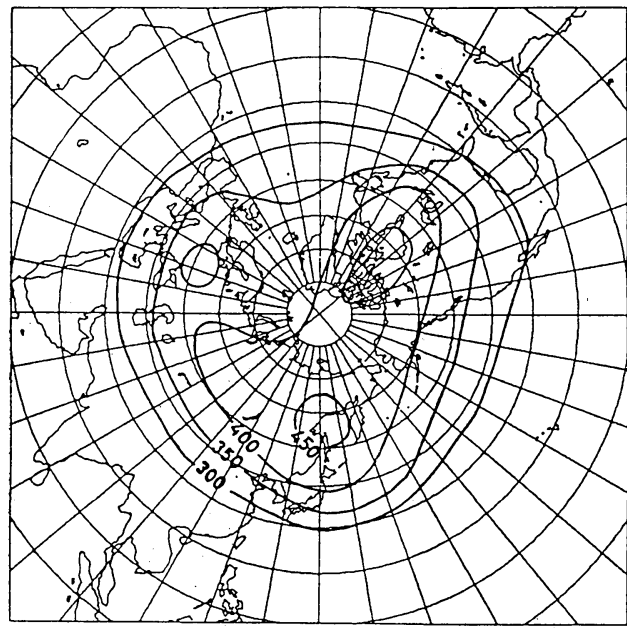

(a)

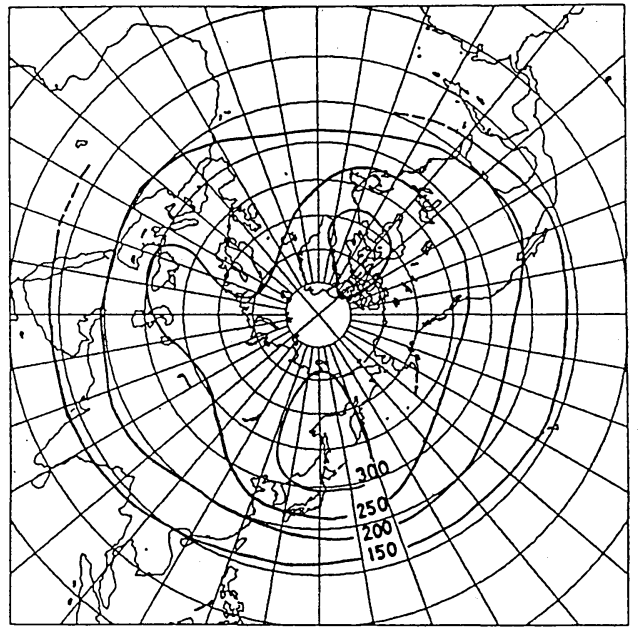

(b)

Fig. 11 February mean distributions of total ozone amount (a) and the lowest tropopause pressure (b) in the northern hemisphere. The former is reported by Shimizu (1971) and the time duration of this statistics is 1960-1970. The dulation of the latter is 1982-1982. The means of the lowest tropopause pressure near the jet stream are somewhat lower than the major tropopause that effectively separates the stratospheric air mass from the tropospheric one, because the multi-tropopause structure is often observed there as shown in Fig. 8. (unit a: $\mathrm{m}$ atm-cm, b: mb)

The total ozone amount at Kagoshima is nearly equal to the zonal mean through all seasons as reported by Dütsch (1971). But the total ozone amount at Sapporo is about $10 \%$ larger than the zonal mean in winter and in spring, so that its latitudinal gradient near Japan is a little larger than the zonal mean one. As shown in Fig. 11, this large gradient leads to the maximum of total ozone amount located near the sea of Okhotsk and the maximum corresponds to that of tropopause pressure. As mentioned above, the main cause of lowering the polar tropopause in the northern side of the jet stream is the adiabatic heating due to the downward motion. Especially, this downward motion is active in the longitudinal region with strong baroclinicity. Therefore, in the region with larger gradient of total ozone amount, the baroclinicity is expected to be stronger. In fact, the wind speed of jet stream over Japan is significantly large and it means that the baroclinicity is strong compared with those in other longitudinal regions.

\section{Conclusion}

The photochemical change rate of ozone has large seasonal and latitudinal variations induced by the distributions of other constituents, temperature and radiative condition. But the ozone density does not satisfy the equlibrium condition, so that the dynamical process is important for its seasonal variation. Particularly, in the mid- and high latitudes, the seasonal variation of total ozone amount is mainly caused by the density variation in the non-steady region. In this case, the dynamical process plays a major role.

At Kagoshima, where the tropical tropopause exists through all seasons, the variation of total ozone amount is mainly caused by the density variation in the steady region and the variation of photochemical creation plays an important role. The time lag between the observed ozone maximum and the summer solstice will be explained by the dynamical effects. On the other hand, the variation at Sapporo is mainly induced by the variation of tropopause structure such that the tropical tropopause changes to the polar one in fall and reversely in spring. In fall, the intra-stratospheric downward motion associated with the extension of stratosphere increases the total ozone amount and in spring the air mass 
release to the troposphere associated with the reduction of the stratosphere decreases it. The reason why the total ozone amount continues to increase during winter is that the distribution of ozone remains at a transient state for the winter circulation. It means that the fall increase in the stratospheric air mass is not only supplied by the intra-stratospheric mass transport, but also by the direct capture of the tropospheric mass.

The longitudinal distribution of total ozone amount is affected by the characteristics of ultra-long planetary wave through the tropopause height. The tropopause height shows a minimum near the sea of Okhotsk, where the total ozone amount becomes a maximum. Therefore, its latitudinal gradient near Japan is large in comparison with the other longitudinal region. This is related to the strong baroclinicity there.

Recently, many authors have attempted to simulate the distributions of minor constituents in the two dimensional models. We think that such the model should contain the seasonal variation of tropopause structure, which is straightforwardly represented by the variation of vertical component of diffusion constant. Because the air mass variation of a hemispheric stratosphere is too large to be negligible.

\section{Acknowledgements}

We would like to acknowledge the valuable comments with Dr. H. Muramatsu and Mr. T. Sasaki of Meteorological Research Institute. In particular, the new informations from them are necessary for the present work, because the understanding on the ozone photochemistry is immediately developing. We thank director E. Terauchi* and chief of technical department M. Kurosawa** of Sapporo district meteorological observatory for their valuable suggestions and encouragements. The authors wish to express their sincere thanks to anonymous referees for their helpful comments.

* Present affiliation: Director of Meteorological Satellite Center.

** Present affiliation: Chief of Weather Forecasting Division of Japan Meteorological Agency.

\section{References}

Aerological Data of Japan (Special Volume), 19701980, (Japan Meteorological Agency).

Brewer A.W., 1949: Evidence for a world circulation provided by the measurements of helium and water vapour distribution in the stratosphere, Quart. J. Roy. Meteor. Soc., 75, 351-363.

Crutzen P. J., 1971: Ozone production rates in an oxygen-hydrogen-nitrogen oxide atmosphere, $J$. Geophys. Res., 76, 7311-7327.

— 1973 : A discussion of the chemistry of some minor constituents in the stratosphere and troposphere, Pure Appl. Geophys., 106-108, 13851399.

Cunnold D., F. Alyea, N. Phillips and R. Prinn, 1975: A three-dimensional dynamical-chemical model of atmospheric ozone, J. Atmos. Sci., 32, 170-194.

Dobson G. M. B., 1956: Origin and distribution of polyatomic molecules in the atmosphere, Proc. Roy. Soc. London, A235, 187-192.

Dütsch H. Cl., 1971: Photochemistry of atmospheric ozone, in Advances in Geophysics, Vol. 15, Academic Press, 219-322.

Galbally I.E. and C.R. Roy, 1980: Destruction of ozone at the earth's surface, Quart. J. Roy. Meteor. Soc., 106, 599-620.

Harwood R. S. and J. A. Pyle, 1977: Studies of the ozone budget using a zonal mean circulation model and linearized photochemistry, Quart. J. Roy. Meteor. Soc., 103, 319-343.

Hidalgo H. and P.J. Crutzen, 1977: The tropospheric and stratosheric composition perturbed by $\mathrm{NO}_{x}$ emissions of high-altitude aircraft, $J$. Geophys. Res., 82, 5833-5866.

Holton J. R., 1980: Wave propagation and transport in the middle atmosphere, Phil. Trans. Roy. Soc. London Ser. A, 296, 73-85.

- and W.M. Wehrbein, 1980: A numerical model of the zonal mean circulation of the middle atmosphere, Pure and Appl. Geophys., 118, 284-306.

Kida H., 1977: A numerical investigation of the atmospheric general circulation and stratospherictropospheric mass exchange: II. Lagrangian motion of the atmosphere, J. Meteor. Soc. Japan, 55, 71-88.

— 1983 : General circulation of air parcels and transport characteristics derived from a hemispheric GCM. Part 1. A determination of advective mass flow in the lower stratosphere, J. Meteor. Soc. Japan, 61, 171-187.

— 1983 : General circulation of air parcels and transport characteristics derived from a hemispheric GCM. Part 2. Very long-term motions of air parcels in the troposphere and stratosphere, J. Meteor. Soc. Japan, 61, 510-523.

Kley D., E. J. Stone, W. R. Henderson, J. W. Drummond, W. J. Harrop, A. L. Schmeltekopf, T.L. 
Thompson and R.H. Winkler, 1979: In situ measurements of the mixing ratio of water vapor in the stratosphere, J. Atmos. Sci., 36, 25132524.

Matsuno T., 1980 : Lagrangian motion of air parcels in the stratosphere in the presence of planetary wave, Pure Appl. Geophys., 118, 189-216.

Muramatsu H., 1980: A case study of the transport of the stratospheric ozone into the troposphere, Pap. Meteor. Geophys., 31, 97-105.

- 1981 : Water budget in the lower stratosphere over Japan, Pap. Meteor. Geophys., 32, $1-17$.

Newell R. E., J. W. Kidson, D. G. Vincent and G. J. Boer, 1972: The general circulation of tropical atmosphere and integrations with extratropical latitudes, Vol. 1, MIT Press, $371 \mathrm{pp}$.

Nicolet M. and W. Peetermans, 1973: On the vertical distribution of carbon monoxide and methane in the stratosphere, Pure Appl. Geophys., 106108, 1400-1416.

Ogawa T., K. Shibasaki and K. Suzuki, 1981: Balloon observation of the stratospheric $\mathrm{NO}_{2}$ profile by visible absorption spectroscopy, J. Meteor. Soc. Japan, 59, 410-416.

Pyle J.A. and C.F. Rogers, 1980: A modified diabatic circulation model for stratospheric tracer transport, Nature, 287, 711-714.

Reed R.J. and K.E. German, 1965: A contribution to the problem of stratospheric diffusion by large- scale mixing, Mon. Wea. Rev., 93, 313-321.

Reiter E. R. and D. Gao, 1982: Heating of the Tibet plateau and movements of the south Asian high during spring, Mon. Wea. Rev., 110, 16941711.

Robinson G. D., 1980: The transport of minor atmospheric constituents between troposphere and stratosphere, Quart. J. Roy. Meteor. Soc., 106, 227-253.

Sakai S., N. Okoshi and T. Miyake, 1980: The distribution of total ozone amount in Japan and its seasonal variation, J. Aero. Obs., 41, 24-32 (in Japanese).

Sekiguchi Y. and H. Kida, 1971: The seasonal variation of total ozone amount in middle latitudes, J. Meteor. Soc. Japan, 49, 95-110.

Schlesinger M.E. and Y. Mintz, 1979: Numerical simulation of ozone production, transport and distribution with a global atmospheric general circulation model, J. Atmos. Sci., 36, 1325-1361.

Shimazaki T. and T. Ogawa, 1974: A theoretical model of minor constituent distributions in the stratosphere including diurnal variations, $J$. Geophys. Res., 79, 3411-3423.

Shimizu M., 1971: Global distribution and seasonal changes of total ozone amount in the atmosphere, Geophys. Mag., 35, 401-429.

Toyama Y., 1979: On the errors of the dew (frost)-point radiosonde and its improvement, Pap. Meteor. Geophys., 30, 93-109 (in Japanese).

\title{
日本上空におけるオゾン全量の季節変化に対する 光化学効果と運動学的効果の寄与
}

\author{
岩 崎 俊 樹*・金戸 進 \\ 札幌管区気象台
}

札猊・館野・鹿児島において，オゾンゾンデによって観測されたオゾン濃度の月平均值に基づき，オゾンの 光化学過程の季節変動を調べた。次に算出されたオゾン濃度の光化学過程による変化率（生成と消隇の差）と 实際に観測された濃度変化とを用いてオゾンの発散量を評価した。

鹿児島におけるオゾン全量の季節変化は主として光化学変化率が発散量とほぼ釣り合っている準定常領域に おける濃度变化に起因している。これに対し，札幌における变化は非定常領域における力学的効果に支配され ている。この場命, 主要な効果は圈界面高度の季節変動であり, 第 2 の効果は子午面循環によってもたらされ た下部成譜圈に打ける萃積効果である。前者は全量の極大を冬にする傾向があるが，後者はそれを春に遟らせ る働きがある。特に冬期間のオゾン全量の增大は，オゾンの分布が冬期の循環に対して過渡的な状態に留って いることを示唆している。オゾン全量の季節変化に関するこの 2 つの観測点間の著しい相違は圈界面の季節変 化に関係している。成層圈質量と対流圈質量を実質的に分ける主要な圈界面は鹿児島の場合は一年中熱帯圈界 面であるのに対し，礼幌の場合は夏には熱帯圈界面であるが冬には極圈界面となるからである。

最後に経度依存性といら観点から日本上空のオゾン分布を考察する。

現所属: 気象庁電子計算窒 